IZA DP No. 6286

Whom to Choose as a Team Mate?

A Lab Experiment about In-Group Favouritism

Andrea Hammermann

Alwine Mohnen

Petra Nieken

January 2012 


\title{
Whom to Choose as a Team Mate? A Lab Experiment about In-Group Favouritism
}

\author{
Andrea Hammermann \\ RWTH Aachen University \\ Alwine Mohnen \\ Technische Universität München \\ and IZA \\ Petra Nieken \\ University of Bonn
}

Discussion Paper No. 6286

January 2012

IZA
P.O. Box 7240
53072 Bonn
Germany

Phone: +49-228-3894-0

Fax: +49-228-3894-180

E-mail: iza@iza.org

\begin{abstract}
Any opinions expressed here are those of the author(s) and not those of IZA. Research published in this series may include views on policy, but the institute itself takes no institutional policy positions.

The Institute for the Study of Labor (IZA) in Bonn is a local and virtual international research center and a place of communication between science, politics and business. IZA is an independent nonprofit organization supported by Deutsche Post Foundation. The center is associated with the University of Bonn and offers a stimulating research environment through its international network, workshops and conferences, data service, project support, research visits and doctoral program. IZA engages in (i) original and internationally competitive research in all fields of labor economics, (ii) development of policy concepts, and (iii) dissemination of research results and concepts to the interested public.
\end{abstract}

IZA Discussion Papers often represent preliminary work and are circulated to encourage discussion. Citation of such a paper should account for its provisional character. A revised version may be available directly from the author. 


\section{ABSTRACT \\ Whom to Choose as a Team Mate? A Lab Experiment about In-Group Favouritism}

The practical relevance of favouritism among students of the same study path is evident in lifelong memberships in fraternities or sororities or in high donations to faculties. In our study, we focus on the in-group favouritism of students by examining the trade-off of acting based on in-group favouritism or a performance signal when decisions are made about whom to choose as a team mate. The novel feature of your study is that the choice of a team mate is either benevolence or relevant to the own output. In the first scenario, only the payoff of the chosen subject changed, whereas in the second scenario, the decision affected the decider's own payoff as well as that of the chosen subject. The subjects ex ante knew the group type (path of study) of the pool of possible team mates and received a signal giving weak information about their ability regarding the task. Intuitively, one would expect more favouritism if the own payoff was not affected by the performance of the chosen team mate. However, we found the opposite. The subjects exerted more favouritism in the revenue sharing scenario. Possibly they expected reciprocal behaviour and less free riding if they selected a team mate belonging to their own group. Interestingly, groups formed based on favouritism did not perform significantly different from groups formed based on the performance signal.

JEL Classification: $\quad$ C92, D03, J71, M51

Keywords: lab experiment, favouritism, teams

Corresponding author:

Alwine Mohnen

Technische Universität München

Chair of Corporate Management

Arcisstrasse 21

80333 Munich

Germany

E-mail: Alwine.Mohnen@tum.de 


\section{Introduction}

Performance should matter, but often we observe that social affiliation plays a crucial role in the probability whowill climb the social ladder. Universities such as the Harvard Business School or exclusive consulting firms such as McKinsey have optimised “old boys' networks,” providing their members with influential contacts for fast track careers. As for universities, lifelong memberships in fraternities, sororities, and alumni clubs are clear evidence that the shared experience of attending the same courses and the same social events during the years of study is a strong foundation for building social networks. But do we observe those networks because people like to favour each other or do they have reasons to believe that their former colleagues will perform better than others? Additionally, will it pay to favour someone because he acts more reciprocal and will people be more or less prone to exert favouritism if their own payoff is affected by the decision?

In our study we address these questions in a controlled laboratory experiment. First, we investigate the decisions of individuals who only have information about a group stereotype and a weak but informative performance signal. Second, we distinguish between scenarios where the decision has monetary consequences for the decider and where his own payoff is not affected. To the best of our knowledge we are the first to incorporate monetary consequences for the decider in such a setting while it is intuitive that favoring someone in reality can affect the own reputation or the output. Third, we test whether favouritism leads, on average, to higher or lower performance. Whereas previous experimental studies concentrated on distributional games (i.e., Charness(2007)) or promotion decisions (i.e., Eberlein/Walkowitz (2008)), we focus on the decision whom to choose as a team mate. Team mate choice is far from being limited to sport teams but can be extended to the selection of employees on the same hierarchy level interacting in a department or project team. We restrict ourselves to providing information about a weakly informative performance signal and a group stereotype. This information resembles typical credentials submitted in recruiting situations and functions as a signal of ability. Furthermore, the team situation is quite intuitive because after hiring or promotion decisions the supervisor and the chosen employee often work closely together. Only in some cases does this also imply a shared outcome. Hence, we distinguish between a situation where the decision leads 
to an increase in the payoffs of the chosen employee and the decider individually and a situation where the payoff is shared between both.

As group characteristics we use study paths, i.e., industrial engineering and business economics. The students of both courses attend some lectures together at RWTH Aachen University ${ }^{1}$ and do not only compete for grades but also, to some extent, for future job vacancies. Generally, a great deal of rivalry can be observed between the two groups ensuring a clear perception of in- and out-group members. Students of industrial engineering apparently feel superior to students of business economics. When comparing the treatment with and without revenue sharing, one would expect the extent of exerted favouritism to be higher if the decider's payoff is not affected by his choice. However, in-group favouritism occurs more often under the revenue sharing condition. Moreover, as we expected, a larger difference in the ability signals reduces favouritism, whereas a stronger group commitment (measured by study length and feelings of group superiority) increases favouritism. Interestingly, we find no efficiency differences in our data when comparing outcomes of decisions following the performance signal and those based on favouritism. Hence, our data do not show that favouritism leads to lower outcomes.

In the following we like to discuss some of the related literature. The phenomenon of favouritism is the focus of both, sociology and economics. For overviews of existing literature in both disciplines, see, for example,Hewstone et al. (2002) or Akerlof/Kranton (2000). From the economic point of view, it seems puzzling that people decide to act favourably on behalf of others even at their own expense. This behaviour becomes even more puzzling whenfavouritism occurs not between close friends (Belot/van de Ven (forthcoming)) or people personally known to each other (Brandts/Solà (2006)) but between strangerswho only share stereotypical qualities, as in our study. Other possible stereotypes are, for instance, nationality (Ben-Ner et al. (2009)), gender (Abrevaya/Hamermesh (2010)), similar lifestyles, or tastes (Chen/Li (2009)). Favouritism of people with specific stereotypicalqualities implies afavouring of specific group members in anonymous settings (Falk/Zehnder (2007)) or even

\footnotetext{
${ }^{1}$ As a result of the German Excellence Initiative, RWTH Aachen University, along with eight other universities, has been awarded the status of an elite university. RWTH Aachen University was primarily chosen for its excellent engineering study paths and is therefore best suited for investigating in-group favouritism between students.
} 
random assignments (Goette et al. (2006)) without any beneficial reputation building. Fehr et al. (2011) have shown the deep-rootedness of altruism toward in-group members and of hostile acts against out-group members develop early on in adolescence. This behaviour seems to be based on a sense of positive group identification (see the social identity theory by Tajfel/Turner (1979)). The main questions focused on by sociological researchers are aboutwhat determines group identity (Hewstone et al. (2002)) and the extent to which in- and out-group members are judged differently. Regarding the latter question,there are some contradicting theories.While Linville/Jones (1980)postulatedthat out-group members are judged either too harshly or too favourablythe 'black sheep theory' of Marques et al. (1988), arguesthe opposite, in that a extremer judgment of in-group members (for experimental evidence supporting the latter theory seefindings by Lewis and Sherman (2003)). An experimental study by Hoff et al. (2011) suggest that the evaluation of inand out-group behaviour depends on the anticipatedrelative status of the own group. The authors find that high status group members are more willing to punish norm violations towards their group members than members of low status groups. The last theory is able to explain some of our divergent results for business economics and industrial engineers.

Concerning the overall efficiency findings regarding social-ties are ambiguous. On the one hand, Prendergast and Topel (1996) have argued that favouritism can lead to less productive job assignments by mismatching and imposing a higher risk on workers. In its extremes, favouritism of in-group members may even express itself in discrimination against out-group members, which has been a problem on the labour market and has been in the focus of legislators as well as researchers (Bertrand/Mullainathan (2004)). On the other hand, social proximity can also be beneficial for firms in terms of better job matches based on more information by the means of informal recruiting channels (Ponzo/Scoppa (2010)), and more successful employees due to higher peer pressure (Mohnen et al. (2008)) or positive reciprocity (Dohmen et al. (2009)) among related workers. Reciprocity might also explain some of our results concerning the absence of inefficient favouritism. Charness et al. (2007) provided experimental evidence that social connections lead to more coordination in battle of sexes games and less cooperation with out-group members in a dictator game. This shows that social proximity can lead to both positive and negative effects. 
To preclude potentially detrimental effects of favouritism, managerial incentives can be used to rationalise the decision making of managers concerning their subordinates. A field study by Bandiera et al. (2009) has shown that switching from fixed pay to an output-related bonus system leads to less managerial effort in favour of socially connected subordinates. In our case, as mentioned before, monetary consequences have the opposite effect.

The remainder of the paper is organised as follows. In section 3, we introduce our hypotheses, followed by a description of the experimental design in section 4 . The results are presented in section 5 . Section 6 concludes with a short summary.

\section{Hypotheses}

To analyse different intentions of favouritism and their effect on the average group performance, we conducted two treatments, the“Baseline" and the "Mixed Payoffs" treatment. In the Baseline treatment, the choice of a team mate did not affect the decider's monetary payoff, but his choice raised the payoff of the chosen subject with whom he interacted during a team task (solving a crossword puzzle). In the Mixed Payoffs treatment, in addition to deciders and subjects interacting as teams during the team task, the subjects' payoff was based on their team output in the working round. Hence, in this treatment, the selection decision also affected the expected payoff of the decider. As a group characteristic, we used the study paths of industrial engineers and business economists.

First of all, we expect the occurrence of in-group favouritism in an anonymous experimental setting. Study paths are a group characteristic students highly identify with. Belonging to a specific study path provides self-esteem,depending on the low or high assumed status of the respective path. Moreover, both groups are close enough to trigger social comparison and rivalry. The university's impact on students' selfperception, even after graduation, is also evident in lifelong memberships in fraternities and sororities or high donations to faculties or universities. Both the distinctness of the objective performance signal and the implementing of monetary consequences (as in Bandiera et al. (2009), Berger et al. (2011)) should reduce the 
occurrence of favouritism. When the decider's decision has monetary consequences for him, he faces a trade-off. If he selects the subject with the highest performance signal, he will maximise his expected payoff. However, if he exerts favouritism and selects the subject with the same study path who is not the best performer, he has a lower expected payoff but perhaps also a positive utility from exerting favouritism. Concerning efficiency, we follow the mismatching argument by Prendergast/Topel (1996), which assumes a decline in the overall outcome of teams where the decider opts against the signal. Our hypotheses concerning the occurrence and effect of favouritism are as follows:

Hypothesis 1: We expect less favouritism in the Mixed Payoffs treatment than in the Baseline treatment because in the Baseline treatment opting against the performance signal does not affect the expected payoff of the decider.

Hypothesis 2: The occurrence of favouritism should decline if a performance signal becomes more distinct (the difference between the subjects' signals is larger) due to guilt aversion of opting against the signal.

Hypothesis 3: As group identification grows over time, we expect that students who have studied over a longer period of time make decisions more often based on favouritism.

Hypothesis 4: Exerting favouritism will not be efficient for the maximization of overall payoff in both treatments. In the Mixed Payoffs treatment, we expect a lower average payoff if the decider exertsfavouritism.

\section{Experimental Design}

As laid out in the previous sections, empirical data sets investigating the effects of social proximity or in-group biases are rare and focus mainly on the occurrence of favouritism (see, e.g., Breuer et al. (2010)). In our experiment, we focus on the circumstances leading to in-group biases and examine whether monetary consequences for the decider induce decisions in favour of in-group members. For 
this reason we conducted a real effort experiment (see Fig. 1 for a time schedule) using z-tree by Fischbacher (2007).

Figure 1: Time Schedule of the Experiment

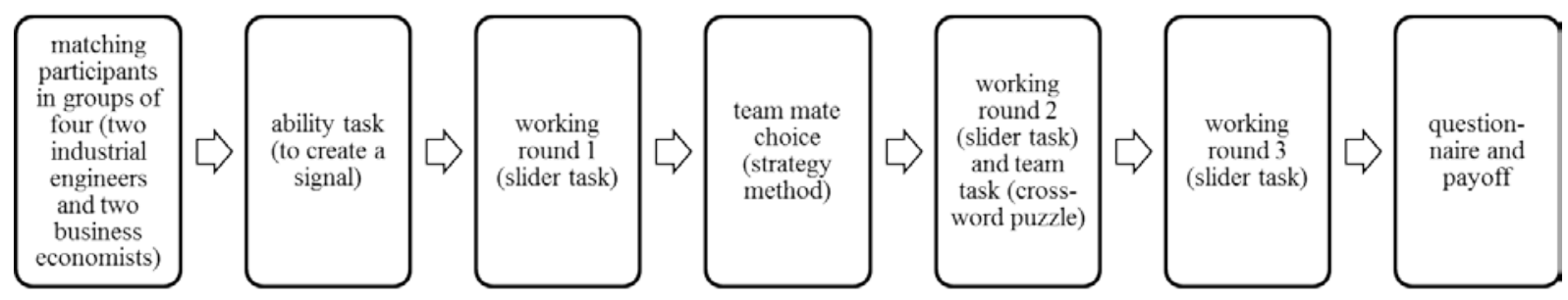

Upon arrival of the subjects at the lab, they were randomly matched into groups of four, i.e., two students each from industrial engineering and business economics. This matching procedure was common knowledge. The experiment consisted of three rounds, preceded by an ability task in which subjects had to click on as many points, appearing all over the screen, as they were able to during two minutes (scores) (see Fig.B1 in the Appendix). The number of scores was used as a signal for subjects to evaluate the general ability of their group members. Each subject learned the scores of the other group members but was not informed about his own performance. The ability task was weakly correlated with the real effort task used later in the experiment $(0.261(p=0.002))$ and did not differ significantly between students of both study paths. Afterwards the first of three identical working rounds began. During these rounds subjects were shown screens full of sliders (see Fig. 2) which had to be adjusted correctly in the middle of 0 and 100 (the task has been introduced by Gill/ Prowse (2011)). For each slider which was moved to “50" subjects earned 5 cents. Each working round lasted 8 minutes. Alternatively, subjects could decide to play a computer game (Tetris). The game was offered as an outside option and did not contribute to the payment. 
Figure 2: Slider Task and Outside Option during the Working Rounds

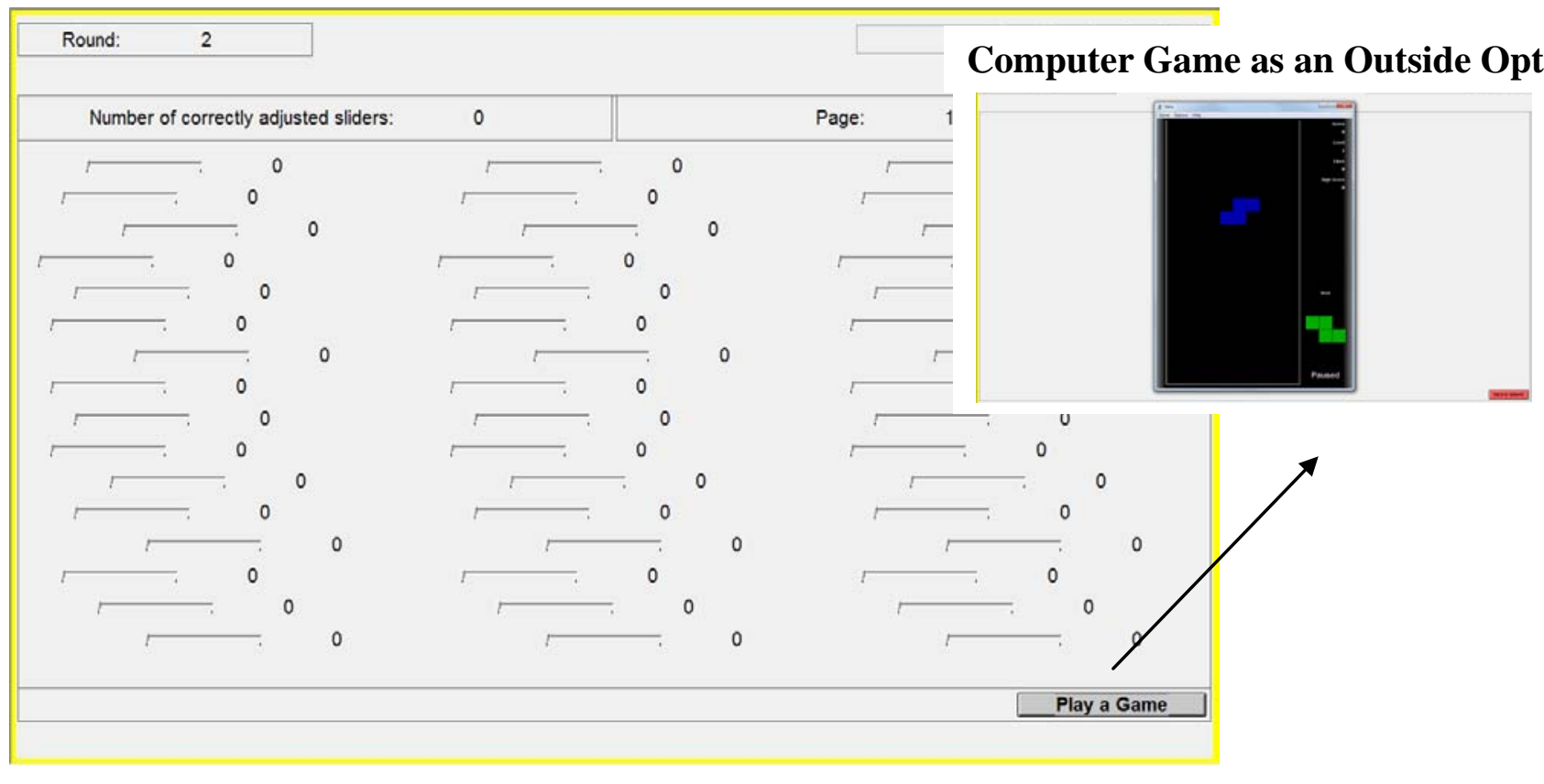

Before the second working round began, each subject had to choose one of his three group members who then received an upgrade of the variable pay (this was doubled from 5 to 10 cents). Subjects had information only about the group members' performance in the ability task and their study paths. We implemented the strategy method (Selten (1967)),according to which each subject had to select one other player. Afterwards one of the four subjects was randomly selected and his decision implemented. This procedure was known by the subjects ex ante. Note that the payment of the decider was also adjusted to the higher piece rate of 10 cents. By paying both the decider and the selected subject an equal piece rate, the idea of equal team members was strengthened, and any negative feelings of the decider, such as envy, were avoided. To investigate if monetary consequences for the decider would influence his selection, we designed two treatments. In the "Baseline" treatment, the team mate decision did not affect the decider's own payoff. He and the chosen subject each worked on their own for a piece rate of 10 cents, whereas the other two players worked again for 5 cents each in round 2. In contrast, in the Mixed Payoffs treatment the payoff of the decider and the selected subject were split equally. The same payoff splitting was implemented for the remaining two subjects who now formed the other team. Out of the group of four, we thus formed two two-party teams. By forming two teams out of a group of four, we enhanced the anonymity of the team mate decision and also strengthened team identity by suggesting a competitive situation such as "we 
against the two others.” In the Mixed Payoffs treatment, we made it clear that the decider's selection would affect his own payoff. In the following, to emulatea real work situation, all subjects in both treatments had to interact in their two-party teams to accomplish a team task. This consisted of solving a crossword puzzle about the City of Aachen, in which one player of one team had to fill in the answers, whereas the other could give hints by using a chat option. The solving of the crossword puzzle did not affect the monetary payoffs. After completion of the puzzle the last round started,in which all subjects again worked for a piece rate of 5 cents. This round was conducted to control for tiring or learning effects. After payments were disclosed each subject completed a questionnaire including questions about personal characteristics and intentions regarding the decision made.

The experiment was conducted at the lab “AIXperiment” in Aachen, Germany, during October 2010 and January 2011. ${ }^{2}$ We invited students enrolled in business economics and industrial engineering via ORSEE (Greiner (2004)). One hundred and thirty-six students participated in a total of seven sessions (three Baseline and four Mixed Payoffs sessions), with 20 subjects participating in each session. ${ }^{3}$ Our sample consisted of $69 \%$ male subjects whose average age was 24 (see Table A1 in the Appendix). The experiment took one and a half hours, and subjects were paid 16 euros (1 euro equalling roughly 1.43 U.S. dollars at the time of the experiment) on average.

\section{Results}

\subsection{In-Group Favouritism}

We implemented the slider task introduced by Gill and Prowse (2011) as a real effort task because it overcomes some of the usual drawbacks of other real effort tasks (counting numbers or solving mathematical equations). In particular, it does not require any pre-existing knowledge, is simple to understand, and resembles effort because it involves little randomness and leaves no scope for guessing. But the most important aspect in the context of our experimental design was that neither industrial

\footnotetext{
${ }^{2}$ The translated instructions can be found in the Appendix.

${ }^{3}$ With the exception of session 6 , where only 16 out of 20 participants showed up.
} 
engineers nor business economists were likely to be better at adjusting sliders. To test for beliefs regarding differences in abilities, we conducted a questionnaire, which was unconnected tothe actual experiment.We asked students of all faculties if they considered the task easier for industrial engineers or business economists or women or men, respectively. The majority of 132 responders did not believe ability played a role in terms of study path (64\%) or gender (55\%). Hence, selecting a subject based on his study path cannot be justified by the expectation that different abilities are required to perform the slider task. Moreover, as can be seen in Figure A1 (in the Appendix), both the ability task and the slider task of the first working round show a similar distribution in both treatments. ${ }^{4}$

Due to the strategy method, we observed 136 selection decisions. Out of those, $56 \%$ followed the given performance signal, with 36 choices of the student from the same study path (hereafter fellow student)and 40 choices of the student from the other student path (hereafter other student). Favouritism, defined as a selection decision that does not follow the performance signal in favour of a fellow student, was quite common in both our treatments. Twenty-one percent decided in favour of the fellow student even if his performance signal was lower than that of the other students(strong favouritism), and $7 \%$ opted for the fellow student if his signal was equal to the best signal of both other group members (weak favouritism). However, the fraction of outgroup favouritism, defined as the decision that favours the other student even if the fellow student was superior with regard to the performance signal, was surprisingly large (13\%). As shown in Figure 3, there is a significantly higher occurrence of favouritism in the Mixed Payoffs treatment than in the Baseline treatment (Fisher test $\mathrm{p}=0.087^{5}$ ). When splitting the sample by study paths, we note that the result is driven by the decisions of the industrial engineers. The difference remains significant ( $p=0.053)$ in contrast to business economists $(p=0.579) .{ }^{6}$ In the following subsection,

\footnotetext{
${ }^{4}$ The first session had to be excluded for the distribution of the ability task because there was a computer problem prolonging the task time at this stage beyond the task times of the other sessions and therefore making any comparison between sessions impossible. Within the session, however, the relative signals remained unaffected

${ }^{5}$ All test results in the paper are reported two-sided.

${ }^{6}$ The significant effect remains robust if we focus exclusively on the decisions where favouritism of fellow students is possible, excluding those where no trade-off between the signal and the group type occurs.
} 
we give a possible explanation why industrial engineers exert more favouritism than business economists.

Figure 3: In-Group Favouritism divided between Treatments

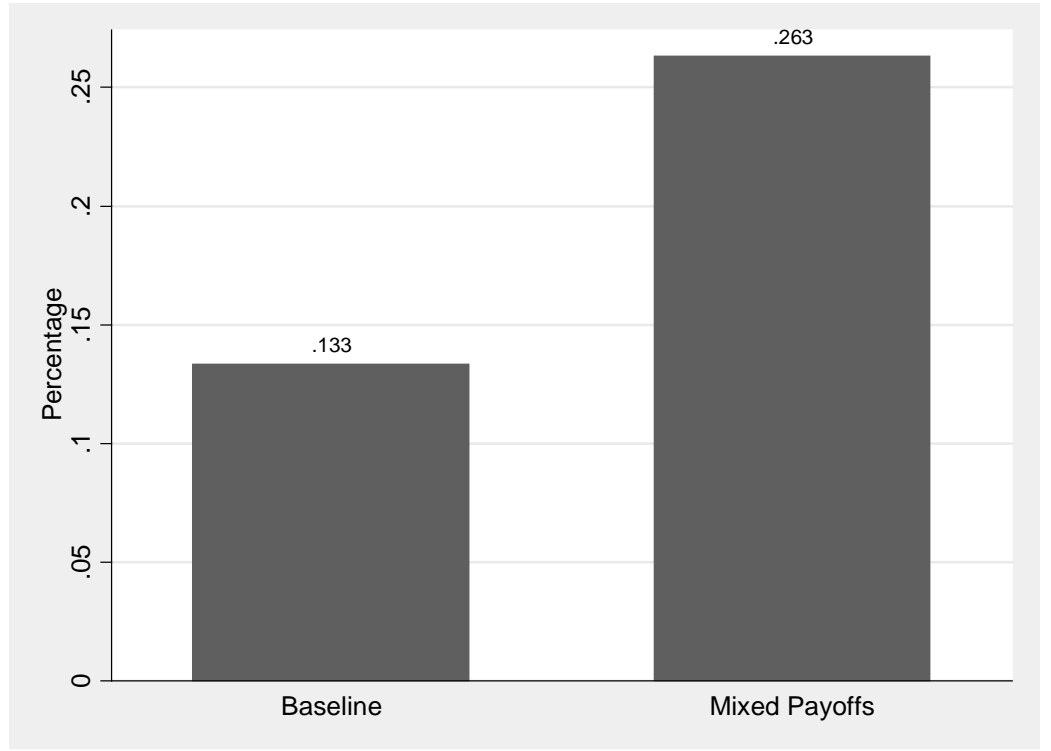

\section{Result 1: In-group favouritism occurs more often if the decision has a monetary consequence for the decider in the form of a revenue sharing compensation system.}

Result 1 is noteworthy and contradicts Hypothesis 1 because it implies an increase in favouritism if the decision is not only favourable for the promoted subject, as in the Baseline treatment, but also affects the deciders' own outcome as in the Mixed Payoffs treatment. There are three possible explanations. First, they may want to ensure that their in-group earns more money than the subjects with a different study path. Second, subjectsfrom the same study path may feel that they have more information about fellow students. Therefore, they opt against the noisy performance signal and believe that the group (study path) is a more reliable predictor of actual performance in the slider task. However, the questions remains why students did not opt against the performance signal when there was no monetary consequence for them as in the Baseline treatment. Here the third explanation might fit. It seems that favouritism is not (only) about being kind to an in-group member but is based on more strategic considerations. If subjects believe that a fellow student tends to be reciprocal and less likely to freeride when chosen, this may overcome the potential disadvantages of selecting a less able team mate. The reciprocal aspect of favouritism has also been 
found in a field experiment in an Israeli kibbutz, a modern collective of people voluntarily engaged in social, national, and military service. The study by Ruffle and Sosis (2005) found kibbutzmembers to be more cooperative if paired with another kibbutz member than with a city resident in a dilemma pool. Thus, even if it turned out that kibbutz members were no more cooperative than city members, the exanteanticipation of more cooperativeness also led to more cooperation with ingroup members.

\subsection{Sources of In-Group Favouritism}

One necessary assumption for in-group favouritism impliesthat individuals identify with the group and associatepositive qualitieswith its members. In accordance with Hewstone et al. (2002), group members of numerical minorities and those with highstatus should show more favouritism, whereas those with lowstatus should show out-group favouritism if the status difference is sufficiently large and they assume their inferiority is legitimated. In the same vein, we asked all participants about their perception of some more or less desirable characteristics of their own study path compared to the other study path. In particular, we asked them if they agreed to the statement (based on a five point Likert scale) that their study path is more demanding and has better final grades or better future perspectives. In addition, we asked them if they thought fellow students were more cooperative, more determined, more egoistic, more intelligent or had better mathematical or linguistic skills. All of those characteristics should give us an impression about a subject's commitment to its own group and its prejudice against the members of the other group. We observe a clear difference in self-perception between industrial engineers and business economists. According to a Fisher test comparing both groups of students, industrial engineers have a significantly stronger belief that their fellow students are more determined $(p=0.000)$ and intelligent $(p=0.000)$. They also believe they have better mathematical abilities $(\mathrm{p}=0.000)$ and that their study path is more demanding $(\mathrm{p}=0.000)$ with better future perspectives $(\mathrm{p}=0.000)$ compared to those of business economists. But in terms of mathematical abilities, industrial engineers are correct, i.e., they actually have a significantly better average grade in mathematics $(\mathrm{p}=0.015)$. Business economists, on the other hand, are more confident only of their linguistic skills $(p=0.000)$. A comparison of beliefs and the realised scores, as revealed in the ability task,underlines 
the findings of our questionnaire. Industrial engineers are significantly more overconfident about their own scores compared to business economists (Fisher test, $\mathrm{p}=0.005$ ). According to their self-perception, industrial engineers seem to consider themselves as a high-status group in contrast to business economists. This phenomenon should, of course, not be generalised but is specific to students of RWTH Aachen University,which has been awarded an elite status for industrial engineering buthas only a small business economics department. ${ }^{7}$ Thus, the perceived lower social status of business economists compared to industrial engineers might explain why the latter tend to show more in-group favouritism, whereas business economists show significantly more out-group favouritism (cf. the findings of Lewis and Sherman (2003), who report that groups with lower social status exert less favouritism). Sixteen out of 18 decisions based on out-group favouritismwere made by business economists (Fisher test, $\mathrm{p}=0.001$ ).

Table A2 (in the Appendix) shows probit regressions with the probability of favouring in-group members as the dependent variable. The sample consists of those observations where in-group favouritism was possible (note that the results remain qualitatively unchanged if we include all 136 observations). As can be seen in the table, the treatment effect is stable in all estimated models, as students show more favouritism in the Mixed Payoffs than in the Baseline treatment. In addition, we find support for Hypothesis 2. The signal difference between the fellow student and the better of the two other students in the group has a highly significant negative effect. This effect holds for both treatments. In the Mixed Payoffs treatment, the decider might, out of payoff concerns, refrain from selecting in-group members showing a greater lack of ability for the corresponding task. But in the Baseline treatment, the decision cannot be driven by monetary consequences:opting against a signal seems to generatea feeling of guilt which needs to be justified. Of course, this justification is easier if the difference between the signals is rather low.

\footnotetext{
${ }^{7}$ The minor status of business economics compared to engineering at RWTH Aachen University is also reflected by a ranking of the Wirtschaftswoche journal (Rettig (2011)). This journal (The Wirtschaftswoche) publishes an annual list of the top German universities. Although RWTH Aachen University holds the leading position in the field of electronicand mechanical engineering, it is, as far as business economics is concerned, not among the first fifteen top universities listed.
} 
Result 2: The occurrence of in-group favouritism declines if the difference between subjects' signals is large, and voting against these signals is therefore less easy to justify.

Another finding worth pointing out is the significant influence of study length, which is in line with Hypothesis 3. Evidently, students become more committed to their study path, the longer they have been studying. Moreover, the dummy for feelings of superiority concerning specific abilities, such as being more ambitious, cooperative, and intelligent than students of the other study path, is also significant. Finally, the number of people personally known to participants in a particular session (on average around 0.6 participants) also increases the likelihood of favouritism. This is also intuitive as feelings of group belonging should increase if there is less social distance between group members. Gender and study path, however, have no significant effect on the probability of favouritism if we add all the aforementioned control variables.

\section{Result 3: Students who have studied for a longertime period are more inclined to decide in favourof a fellow student.}

\subsection{Profits and Performance Levels with and without Favouritism}

In the previous section, we analysed the occurrence of favouritism. Here we concentrate on the question how favouritism affects the profit and performance levels of subjects.First, we look at the average team effort accomplished in both treatments of round 2 (see Table 1). Remember that output is shared in the Mixed Payoffs treatment but not in the Baseline treatment. According to standard theory, team output generally suffers from free riding so that we expected lower output levels in the Mixed Payoffs treatment. As Table 1 shows, we find the opposite in our data. The mean effort (average team effort in both treatments) in the Baseline treatment (81 sliders) is significantly lower than in the Mixed Payoffs treatment (85 sliders) (Wilcoxon ranksum test, $\mathrm{p}=0.058$ ).

However, our results may also be driven by differences in abilities or other personal characteristics. We therefore ran an OLS regression controlling for ability and personal characteristics such as gender and study path. Table A3 (in the Appendix) 
shows that revenue sharing has indeed a positive impact on productivity. Expected ability, measured by the ability ${ }^{8}$ task, is highly significant for the team output in all models. In contrast, math grades, included as a measure for general cognitive ability, have no significant impact on performance. The increased piece rate has a large impact, which shows that our subjects responded to monetary incentives because the piece rate was doubled and the profit of this round had a large impact on overall payment. Figure 4 illustrates the development of performance over the three slider task rounds for those who received 10 cents per slider and those who received 5 cents in the second slider task round. Two notable findings can be observed. First, in the second round average performance is significantly higher for those subjects who received 10 cents (on the right side) compared to the performance of those subjects who, received 5 cents, in the second slider task round (t-test $\mathrm{p}=0.065$ ). Hence, it can be concluded that, even if learning effects are evident in our subject pool, the increase in the piece rate has a clear incentive effect. Second, subjects who were paid 10 cents in the second round only slightly reduced their performance in the third (again, all subjects were compensated with a 5 cent piece rate). Thus, we observe no crowding out effects in our subject pool. In the multivariate analysis (Table A3), no evidence for an increase in the performance of homogeneous groups can be found. Note that both variables male andindustrial engineers have a positive effect on the number of accomplished sliders.

\footnotetext{
${ }^{8}$ We do not use the first round of the slider task to control for ability in our regressions because it is highly correlated with the second $(0.718, \mathrm{p}=0.000)$ and third rounds $(0.732, \mathrm{p}=0.000)$. Consequently, performance would have been nearly determined by the first round.
} 
Figure 4: Performance ofSubjects earning 10 cents and those
earning 5 cents after the Team Mate Decision

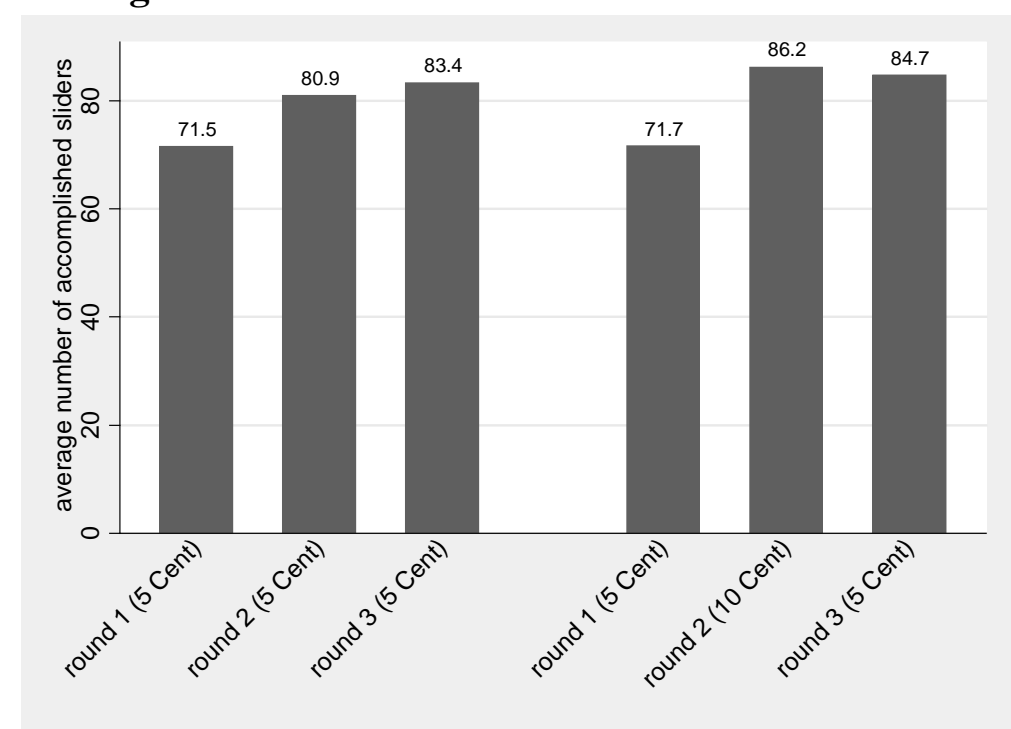

To answer the question if following the signal or exerting favouritism is a better strategy in terms of maximizing expected payoffs, we consider the effort level of those who were selected for the higher payment. This reduces our sample to 34 subjects as only one decision of each group was implemented. Due to the small sample size, we conducted a Wilcoxon rank-sum test,which confirmed that in both treatments and overall no significant differences in profits were found whendeciders who followed the signal and those who exerted favouritism $(p=0.248)$ were compared.

\section{Result 4: There is no significant difference regarding efficiency in terms of profit regardless of whether the decider chooses to follow the signal or to exert favouritism.}

This finding contradicts Hypothesis 4 and is evidence that favouritism is not necessarily negative if (1) ability differences are not large and (2) positive reciprocity compensates the lack of ability in teams. To look deeper into the effect of team mate decisions on effort, we divide the whole sample in those teams receiving 5 respectively 10 cents in the second slider task round. The regression results are shown in Table A4 (in the Appendix). As one might expect, teams who were not selected for the 10 cent piece rate performed worse if the decision was based on the ability signal. Surprisingly, the positive effect of those decisions is not significant for groups receiving 10 cents. Revenue sharing is again weakly significant, but only for groups 
receiving 10 cents. These findings support our assumption that there is some evidence for positive reciprocity. On the one hand, reciprocity could simply occur due to the fact of a subject having been selected as a team mate. However, this would not explain why subjects prefer fellow students. In our setting, subjects do not know their own signal and cannot be sure whether they have been favoured. Nevertheless, they have information about the signals of the three other group members and certainly a belief about their own performance. Hence, when selected by a fellow student, they form a belief that this decision is either based on favouritism or not. Furthermore, the decider seems to believe that a fellow student is less likely to free ride, drivinghis decision no matter what the real intentions of the selected fellow student are. Further results in Table A4 show a positive ability effect and higher group performance of male, left-handed subjects. In general, we find no evidence of any decline in group performance if team mate decisions are based on favouritism. While this is to some extent due to the fact that subjects refrained from exerting favouritism if ability differences were large, smaller ability differences were compensated by positive reciprocity.

\section{Conclusions}

In our paper, we analysed the occurrence and effects of favouritism in a teammate selection process. In a real effort experiment, subjects had to select a team mate based on a weak performance signal and a group stereotype. In one treatment, the decision had no monetary consequences for the decider while in the other treatment,he shared the output with the selected team mate.

While it is often stated that altruistic favours between group members end if money is involved, we find the opposite effect in our data. In our setting, subjects decide more often in favour of a group stereotype (if they know they will share the output with the selected player). We argue that the decider does not foremost act altruistic but expects less free riding and more reciprocity from a member of his in-group than from a member of the out-group. Our subjects were more likely to opt against the performance signal if the difference between signals was rather low. Otherwise their decision would have been hard to justify, and too much money would have been at stake for them. But given this behaviour, we find that this form of favouritism was not harmful to performance. Hence, firms need not worry too much about mild forms of 
favouritism in team mate selection. Further research is needed to investigate if this behaviour can also be found in field experiments and empirical data. It would be especiallyilluminating to analysethe data of fraternities, sororities, and alumni clubs of furtheruniversities, regarding altruism or parochialism of in- and out-group members with different initial status. In addition, it would be intriguing to seeif this phenomenon is stronger when the team has to work together for a longer period of time or when the group members have a long history of friendship. In this setting, it would beworthwhile to analyse the impact of social networks on team mate selection.

\section{Acknowledgments}

Petra Nieken gratefully acknowledges the financial support by the Deutsche Forschungsgemeinschaft (DFG), grant SFB/TR 15. We would like to thank David Gill and Victoria Prowse for sharing the z-tree program of the slider task and René Gassen and Torsten Held for programming the experimental software. Furthermore, we are grateful for valuable comments received at the ESA Conference in Luxembourg and the VereinfürSocialpolitik Conference in Frankfurt. 


\section{References}

Abrevaya, J., Hamermesh, D. (2010): Charity and Favoritism in the Field: Are Female economists Nicer (To Each Other)? IZA Discussion Paper No. 4921.

Akerlof, G.., Kranton, R. (2000): Economics and Identity. The Quarterly Journal of Economics. Vol. CXV Issue 3, pp.715-753.

Bandiera, O., Barankay, I., Rasul, I. (2009): Social connections and incentives in the workplace: Evidence from personnel data. Econometrica, Vol. 77, pp. 10471094.

Belot, M., van de Ven, J. (2011): Friendships and Favoritism on the Schoolground- A Framed Field Experiment. Economic Journal, Vol. 121, Issue 557, pp. 12281251.

Ben-Ner, A., McCall, B., Stephane, M., Wang, H. (2009): Identity and in-group/outgroup differentiation in work and giving behaviours: Experimental evidence. Journal of Economic Behavior\& Organization, Vol. 72, pp. 153-170.

Berger, J., Herbertz, C., Sliwka, D. (2011): Managerial Incentives and Favoritism in Promotion Decisions- Theory and Field Evidence. IZA Discussion Paper, No.5543.

Bertrand, M., Mullainathan, S. (2004): Are Emily and Greg More Employable than Lakisha and Jamal?A Field Experiment on Labor Market Discrimination.Quarterly Journal of Economics. Vol. 94, pp. 991-1013.

Brandts, J., Solà, C. (2010): Personal relations and their effect on behavior in an organizational setting: An experimental study. Journal of Economic Behavior\& Organization, Vol. 73, pp. 246-253.

Breuer, K., Nieken, P., Sliwka, D. (forthcoming): Social Ties and Subjective Performance Evaluations - An Empirical Investigation.Review of Managerial Science.

Charness, G., Rigotti, L., Rustichini, A. (2007): Individual Behavior and Group Membership. American Economic Review, Vol. 97 (4), pp. 1340-1352.

Chen, Y., Li, S. (2009): Group Identity and Social Preferences. American Economic Review, 99:1,pp. 431-457.

Dohmen, T., Falk, A., Huffman, D., Sunde, U. (2009): Homo reciprocans: Survey evidence on behavioural outcomes. The Economic Journal 119 (536), pp. 592612. 
Eberlein, M., Walkowitz, G.. (2008): Positive and Negative Team Identity in a Promotion Game. Discussion Paper 13/2008.

Falk, A., Zehnder, C. (2007): Discrimination and In-Group Favoritism in a Citywide Trust Experiment. IZA Discussion Paper No. 2765.

Fehr, E., Rützler, D., Sutter, M. (2011): The Development of Egalitarianism, Altruism, Spite and Parochialism in Childhood and Adolescence. CESifo Working Paper No. 3361.

Fischbacher, U. (2007): z-Tree: Zurich Toolbox for Ready-made Economic Experiments, Experimental Economics. Vol. 10.2, pp. 171-178.

Gill, D., Prowse, V. (2011): A Novel Computerized Real Effort Task Based on Sliders. Discussion Paper Series in Economics and Econometrics. University of Southampton..

Goette, L., Huffman, D., Meier, S. (2006): The Impact of Group Membership on Cooperation and Norm Enforcement: Evidence Using Random Assignment to Real Social Groups. Economic Consequences of Social Identity. Vol. 96 (2), pp. 212-216.

Greiner, B. (2004): An Online Recruitment System for Economic Experiments. In: Kurt Kremer, Volker Macho (Hrsg.): Forschung und wissenschaftliches Rechnen. GWDG Bericht 63.Ges.fürWiss. Datenverarbeitung, Göttingen, pp. 79-93.

Hewstone, M., Rubin, M., Willis H. (2002): Intergroup Bias. Annual Review Psychology. Vol.53, pp. 575-604.

Hoff, K.R., Kshetramade, M., Fehr, E. (2011): Caste and punishment: The legacy of caste culture in norm enforcement. The Economic Journal 121 (556), pp. 449-475.

Lewis, A., Sherman, S. (2003): Hiring you makes me look bad: Social-identity based reversals of the ingroupfavoritism effect. Organizational Behavior and Human Decision Processes 90, pp. 262-276.

Linville, P., Jones E. (1980): Polarized Appraisals of Out-Group Members. Journal of Personality and Social Psychology. Vol. 38 (5), pp.689-703.

Marques, J., Yzerbyt, V., Leyens, J. (1988). The 'Black Sheep Effect': Extremity of judgements towards ingroup members as a function of group identification. European Journal of Social Psychology, Vol.18, pp.1-16.

Mohnen, A., Pokorny, K., Sliwka, D. (2008): Transparency, inequity aversion, and the dynamics of peer pressure in teams: Theory and evidence. Journal of Labor Economics 26 (4), pp. 693-720. 
Ponzo, M., Scoppa, V. (2010): The use of informal networks in Italy: Efficiency or favoritism? The Journal of Socio-Economics, Elsevier, Vol. 39 (1), pp. 89-99.

Prendergast, C., Topel, R. (1996): Favoritism in organizations. Journal of Labor Economics 20, pp.115-137.

Rettig, D. (2011),: Vom Hörsaal auf den Chefsessel. WirtschaftsWoche Nr. 16 vom 18.04.2011, pp.84 / Management \& Erfolg.

Ruffle, B., Sosis, R. (2006): Cooperation and the in-group-out-group bias: A field test on Israeli kibbutz members and city residents. Journal of Economic Behavior \& Organization, Vol. 60, pp. 147-163.

Selten, R. (1967): Die Strategiemethode zur Erforschung des eingeschränkt rationalen Verhaltens im Rahmen eines Oligopolexperiments, Beiträge zur experimentellen Wirtschaftsforschung, Heinz Sauermann (ed.), Vol. I, Tübingen: J.C.B. Mohr (Siebeck), pp. 136-168.

Tajfel, H., Turner, J. (1979): An integrative theory of intergroup conflict. In: Austin, W.G., Worchel, S. (Eds.), The Social Psychology of Intergroup Relation. Brooks-Cole, Monterey, CA, pp. 33-48. 


\section{Appendix}

\section{A. Tables and Figures}

Table A1: Summary Statistics

\begin{tabular}{|c|c|c|c|}
\hline Variable & Description & Mean & Std. Dev. \\
\hline $\begin{array}{l}\text { Following the } \\
\text { signal }\end{array}$ & $\begin{array}{l}\text { Dummy equals } 1 \text { if the decider chose on the basis of the } \\
\text { signal }\end{array}$ & 0.559 & 0.498 \\
\hline Favouritism_own & $\begin{array}{l}\text { Dummy equals } 1 \text { if the decider chose a fellow student } \\
\text { against a higher signal of other students }\end{array}$ & 0.206 & 0.406 \\
\hline Favouritism_other & $\begin{array}{l}\text { Dummy equals } 1 \text { if the decider chose one of the other } \\
\text { students against a higher signal of his fellow student }\end{array}$ & 0.132 & 0.340 \\
\hline Own signal & No. of clicked points in the ability task & 56.287 & 13.850 \\
\hline Max_economists & $\begin{array}{l}\text { Mean best signal (no. of clicked points) of business } \\
\text { economists }\end{array}$ & 56.007 & 13.909 \\
\hline Max_engineers & $\begin{array}{l}\text { Mean best signal (no. of clicked points) of industrial } \\
\text { engineers }\end{array}$ & 59.515 & 12.828 \\
\hline Profit & Average profit (in euros) & 16.018 & 3.444 \\
\hline Iime1 & $\begin{array}{l}\text { Time of playing the computer game in the first slider round } \\
\text { (in sec.) }\end{array}$ & 3.897 & 29.067 \\
\hline Time2 & $\begin{array}{l}\text { Time of playing the computer game in the second slider } \\
\text { round (in sec.) }\end{array}$ & 0.436 & 4.106 \\
\hline Time3 & $\begin{array}{l}\text { Time of playing the computer game in the third slider round } \\
\text { (in sec.) }\end{array}$ & 2.472 & 12.728 \\
\hline Effort1 & Accomplished sliders in the first slider task round & 71.603 & 14.595 \\
\hline effort2 & Accomplished sliders in the second slider task round & 83.574 & 16.673 \\
\hline Effort3 & Accomplished sliders in the third slider task round & 84.037 & 17.708 \\
\hline Male & Dummy equals 1 if participant is male & 0.691 & 0.464 \\
\hline Age & Age of participants & 23.875 & 3.595 \\
\hline Left-handed & Dummy equal 1 if participant is left-handed & 0.096 & 0.295 \\
\hline Mathgrade & Last math grade in the universityentrance diploma & 2.037 & 0.794 \\
\hline Signal difference & $\begin{array}{l}\text { Dummy equals } 1 \text { if the differences between signals is equal } \\
\text { to or more than six clicked points ( } 6 \text { points is average } \\
\text { difference) }\end{array}$ & 0.456 & 0.500 \\
\hline Study length & $\begin{array}{l}\text { Dummy equal } 1 \mathrm{~s} \text { if the subject studied for more than } 9 \\
\text { semesters ( } 75 \% \text { percentile) }\end{array}$ & 0.272 & 0.447 \\
\hline Known_personally & $\begin{array}{l}\text { No. of participants of respective session personally known to } \\
\text { the subject }\end{array}$ & 0.618 & 1.096 \\
\hline Superior & $\begin{array}{l}\text { Dummy equals } 1 \text { if subject believed his study path and its } \\
\text { students were superior in terms of more than three out of six } \\
\text { of the following characteristics: ambitious, cooperative, } \\
\text { determined, intelligent, better math, and linguistic abilities) }\end{array}$ & 0.338 & 0.475 \\
\hline
\end{tabular}


Figure A1: Density Plot of Both Ability Task and First Round of Slider Task
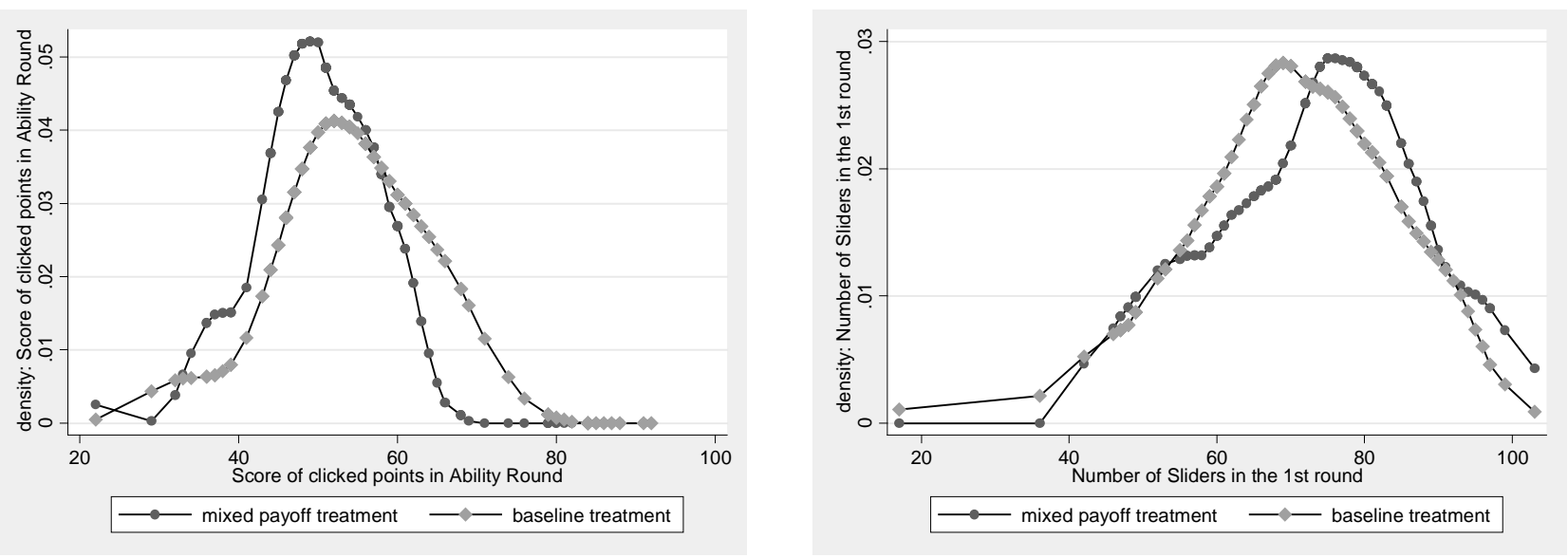

Table A2: Occurrence of In-Group Favouritism in Team Mate Decision

\begin{tabular}{|c|c|c|c|c|}
\hline In-Group Favouritism & $(1)$ & $(2)$ & (3) & $(4)$ \\
\hline Mixed payoffs (Dummy) & $\begin{array}{c}0.657 * * \\
(2.13)\end{array}$ & $\begin{array}{c}0.661^{* *} \\
(2.02)\end{array}$ & $\begin{array}{c}0.699 * * \\
(2.01)\end{array}$ & $\begin{array}{c}0.720 * * \\
(2.07)\end{array}$ \\
\hline Signal difference (Dummy) & & $\begin{array}{c}-1.065^{* * *} \\
(-3.20)\end{array}$ & $\begin{array}{c}-1.070 * * * \\
(-3.18)\end{array}$ & $\begin{array}{c}- \\
1.107^{* * *} \\
(-3.15)\end{array}$ \\
\hline Study length (Dummy) & & $\begin{array}{c}0.911 * * * \\
(2.59)\end{array}$ & $\begin{array}{c}0.906 * * \\
(2.26)\end{array}$ & $\begin{array}{c}1.071^{* *} \\
(2.36)\end{array}$ \\
\hline Math grade & & $\begin{array}{l}0.246 \\
(1.23)\end{array}$ & $\begin{array}{l}0.254 \\
(1.23)\end{array}$ & $\begin{array}{l}0.343 \\
(1.60)\end{array}$ \\
\hline $\begin{array}{l}\text { Industrial engineer } \\
\text { (Dummy) }\end{array}$ & & & 0.083 & -0.423 \\
\hline Male (Dummy) & & & $\begin{array}{l}(0.19) \\
-0.138 \\
(-0.34)\end{array}$ & $\begin{array}{l}(-0.77) \\
-0.077 \\
(-0.18)\end{array}$ \\
\hline Known_personally & & & & $\begin{array}{l}0.312^{*} \\
(1.69)\end{array}$ \\
\hline Superior (Dummy) & & & & $\begin{array}{l}0.874^{*} \\
(1.73)\end{array}$ \\
\hline$N$ & 80 & 80 & 80 & 80 \\
\hline
\end{tabular}


Table A3: Average Effort within Teams

\begin{tabular}{|c|c|c|c|}
\hline Average Team Effort & $(1)$ & $(2)$ & $(3)$ \\
\hline Mixed payoffs (Dummy) & $\begin{array}{l}3.637 * \\
(1.83)\end{array}$ & $\begin{array}{c}4.144 * * \\
(2.07)\end{array}$ & $\begin{array}{c}3.975^{* *} \\
(1.99)\end{array}$ \\
\hline $\begin{array}{l}\text { Own signal (number of clicked } \\
\text { points) }\end{array}$ & $\begin{array}{c}0.229 * * * \\
(3.23)\end{array}$ & $\begin{array}{c}0.208 * * * \\
(2.93)\end{array}$ & $\begin{array}{c}0.169 * * \\
(2.46)\end{array}$ \\
\hline Math grade & $\begin{array}{l}-0.762 \\
(-0.57)\end{array}$ & $\begin{array}{l}-0.038 \\
(-0.03)\end{array}$ & $\begin{array}{l}0.490 \\
(0.37)\end{array}$ \\
\hline Higher piece rate (Dummy) & & $\begin{array}{c}4.981 * * \\
(2.34)\end{array}$ & $\begin{array}{c}4.372 * * \\
(2.01)\end{array}$ \\
\hline Homogeneous group (Dummy) & & $\begin{array}{l}-2.115 \\
(-1.04)\end{array}$ & $\begin{array}{l}-2.413 \\
(-1.17)\end{array}$ \\
\hline Industrial engineer (Dummy) & & & $\begin{array}{c}4.383 * * \\
(2.08)\end{array}$ \\
\hline Male (Dummy) & & & $\begin{array}{c}3.937^{*} \\
(1.71)\end{array}$ \\
\hline Left-handed (Dummy) & & & $\begin{array}{l}3.509 \\
(1.21)\end{array}$ \\
\hline $\bar{N} N$ & 135 & 135 & 135 \\
\hline$R^{2}$ & 0.101 & 0.149 & 0.221 \\
\hline
\end{tabular}

Table A4: Average Effort within Teams Separated by Different PieceRates

\begin{tabular}{|c|c|c|c|c|}
\hline \multirow{3}{*}{ Average team effort } & \multirow{2}{*}{\multicolumn{2}{|c|}{$\begin{array}{c}5 \text { Cent Piece Rate } \\
\text { Teams }\end{array}$}} & \multirow{2}{*}{\multicolumn{2}{|c|}{$\begin{array}{c}10 \text { Cent Piece Rate } \\
\text { Teams }\end{array}$}} \\
\hline & & & & \\
\hline & (1) & (2) & (3) & (4) \\
\hline \multirow{2}{*}{$\begin{array}{l}\text { Decision based on signal } \\
\text { (Dummy) }\end{array}$} & $-6.464 *$ & $-5.817 *$ & 2.012 & 1.701 \\
\hline & $(-1.94)$ & $(-1.82)$ & $(0.71)$ & $(0.59)$ \\
\hline \multirow[t]{2}{*}{ Mixed payoffs (Dummy) } & 0.857 & -0.367 & $5.168 *$ & $5.604 * *$ \\
\hline & $(0.27)$ & $(-0.11)$ & $(1.92)$ & $(2.12)$ \\
\hline \multirow{2}{*}{$\begin{array}{l}\text { Own signal (number of clicked } \\
\text { points) }\end{array}$} & 0.038 & -0.019 & $0.275^{* *}$ & $0.270 * * *$ \\
\hline & $(0.37)$ & $(-0.18)$ & (2.61) & (2.89) \\
\hline \multirow{2}{*}{ Industrial engineer (Dummy) } & & 4.332 & & 1.870 \\
\hline & & $(1.30)$ & & $(0.66)$ \\
\hline \multirow[t]{2}{*}{ Male (Dummy) } & & 5.062 & & $6.342 * *$ \\
\hline & & $(1.23)$ & & (2.19) \\
\hline \multirow[t]{2}{*}{ Left handed (Dummy) } & & 0.172 & & $9.785 * * *$ \\
\hline & & $(0.06)$ & & $(3.14)$ \\
\hline 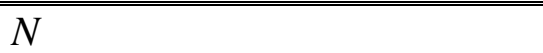 & 68 & 68 & 68 & 68 \\
\hline
\end{tabular}

